Board of Governors of the Federal Reserve System

International Finance Discussion Papers

Number 974

May 2009

\title{
South Africa's Post-Apartheid Two-Step: Social Demands versus Macro Stability
}

\author{
Brahima Coulibaly and Trevon D. Logan*
}

NOTE: International Finance Discussion Papers are preliminary materials circulated to stimulate discussion and critical comment. References in publications to International Finance Discussion Papers (other than an acknowledgment that the writer has had access to unpublished material) should be cleared with the author or authors. Recent IFDPs are available on the Web at www.federalreserve.gov/pubs/ifdp/. This paper can be downloaded without charge from Social Science Research Network electronic library at http://www.ssrn.com/. 


\title{
South Africa's Post-Apartheid Two-Step: Social Demands versus Macro Stability
}

\author{
Brahima Coulibaly and Trevon D. Logan*
}

May 2009

\begin{abstract}
During Apartheid, there was little need for redistributional policies or to borrow for public works since the vast majority of the population was underserved. With the arrival of a representative democracy in 1994, however, South Africa faced a unique problem-- providing new and improved public services for the majority of its citizens while at the same time ensuring that filling this void would not undermine macroeconomic stability. Over the past fifteen years, policy makers have achieved macrostability, but progress on social needs has been below expectations and South Africa continues to lag behind its peers. This paper reviews the progress made so far and examines the challenges ahead for the upcoming administration. Our analysis suggest an increase in skill formation as a possible solution to the policy dilemma of fullfilling the outsized social demands while maintaining macrostability.
\end{abstract}

Keywords: apartheid, social needs, stability, welfare, macroeconomy

JEL classifications: D6, E6, H1, I0, O2

* Coulibaly is staff economist in the Division of International Finance, Board of Governors of Federal Reserve System, Mail Stop 24, Washington DC 20551, U.S.A.; email: brahima.coulibaly@frb.gov; Tel.: (202)-452-2609; fax: (202)-736-5638. Logan is Assistant Professor in the Department of Economics at Ohio State University, 410 Arps Hall, 1945 N. High Street, Columbus, OH 43210; email: logan.155@osu.edu; Tel.: (614) 292-0762. We thank William Darity, Peter B. Henry, Lisa D. Cook, and other session participants of the 2009 American Economic Association annual meetings for helpful comments and discussions. We also thank Patrice Robitaille and Robert Martin for comments, and Sudarshan Sampath, Nathan Wodfork, and Peter Weyand for research assistance. The views expressed in the paper are those of the authors and do not necessarily reflect those of the Board of Governors or the Federal Reserve System. 
Macroeconomic policy prescriptions for a typical emerging market economy generally include a monetary policy consistent with low and stable inflation, a well-aligned exchange rate, sustainable debt levels and fiscal and current account balances. When successfully implemented, these policies help the country achieve macroeconomic stability, raise its solvency, and allows its access to foreign capital at a lower cost. In practice, however, implementation of some of these policies requires cut backs on government spending that conflict with pressing domestic needs for social services. How policymakers strike the right balance between satisfying social needs while ensuring macroeconomic stability remains a constant challenge in emerging economies' development strategies.

The tension between the social needs and policies conducive of macroeconomic stability is particularly heightened in South Africa, owing largely to the unique legacy of Apartheid. ${ }^{1}$ During Apartheid (1948-1994), most of the social spending catered toward the needs of the minority white population while black citizens were underserved. With the end of the regime in 1994, South Africa's new democracy faced a formidable challenge: dramatically increasing the government's role in the provision of social services to its citizens in a way that would not compromise macroeconomic stability. By most measures, post-apartheid policymakers were successful in maintaining macroeconomic stability, but progress on meeting the social demands has been slower. The discontent with the slow pace of social progress gave rise to a new tone in public policy spearheaded by Jacob Zuma (standing president of the African National Congress (ANC)) who has signaled that South Africa may tilt its policy priorities toward social spending programs in the coming years. In September 2008, South Africa's president Thabo Mbeki, who presided over South Africa's longest period of economic growth, resigned under pressure from the ANC. Market responses were swift when it was rumored that senior cabinet officials, notably Finance Minister Trevor Manual, would resign. Markets subsequently rebounded when it was later clarified that he would stay.

Indeed, the sad story of South Africa's neighbor, Zimbabwe, is a particularly ominous example of what can go wrong when the delicate balancing act goes awry. After independence and the establishment of democracy, Zimbabwe pursued a program of social and economic moderation. Social indicators improved, limited landholdings were redistributed, and mass schooling led Zimbabwe to have above average literacy rates for a developing country. Subsequently, Zimbabwe shifted policy to cut back on its social spending to re-assure foreign investors of the government's commitment to

\footnotetext{
${ }^{1}$ Apartheid was a political system in South Africa between 1948 and 1994, during which the white minority population controlled the political process and the economy, and the majority black population was acutely underserved.
} 
macrostability. The reduction in spending on social programs caused political pressure that eventually led to massive land reforms which in turn led to the complete collapse of foreign investment. Inflation rose to the highest levels ever recorded, foreign investment vanished, social spending is now non-existent, mass emigrations are common, and the very institutional structure of the nation is in flux. If the policymakers in South Africa fail to strike the right policy balance, there are concerns that it could meet a similar fate.

While there are no clear answers to South Africa's policy dilemma, our paper reviews the situation and presents a policy option with the goal of stimulating reasoned policy discussions. In the next section we summarize the position of South Africa at present. We use this summary to estimate, roughly, the size of spending on social programs that would cause South Africa to catch up with its economic peers. ${ }^{2}$ Expenditures on health and education alone would raise government expenditures by nearly 140 percent of GDP over a ten year period to close the gap with other uppermiddle income countries. Such a high level of spending is clearly not sustainable, and could threaten macroeconomic stability. The results from a simple two-capital growth model calibrated to South Africa's economy indicate that a higher, but sustainable, government expenditure on investment in human capital can help the country achieve its social demands target without undermining macroeconomic stability.

\section{Macroeconomic and Social Indicators}

\subsection{Macroeconomic Indicators}

For the past fifteen years, South Africa appears to have successfully achieved a stable macroeconomy. Figure 1 shows some key economic indicators. Economic growth rose consistently over the past decade to about 5 percent in recent years, and inflation fell consistently from double digits historically to roughly 5 percent. The budget, which had been in deficits for several years, was reigned in to a surplus and government debt levels fell consistently from a peak of 50 percent of GDP in 1995 to under 25 percent. The exchange rate stabilized in recent years, and the foreign exchange reserves have risen dramatically since 1995. The bond market responded with lower yields; the yield on South Africa's bonds with a maturity of 15 years or longer fell consistently from 16 percent

\footnotetext{
${ }^{2}$ We define economic peers as other upper-middle income countries. "upper-middle income" classification follows the World Bank classification in the World Developement Indicator database. It includes countries such as Bulgaria, Turkey, Poland, Malaysia, Mexico, Brazil, Gabon, and Botswana.
} 
in 1995 to roughly 8 percent. ${ }^{3}$ The significant improvements in the macroeconomic framework has been praised by foreign investors and has earned former President Mbeki and his government, notably Finance Minister Trevor Manual, the reputation of a market friendly administration.

On domestic social issues, however, the Mbeki administration has not been praised by South Africans primarily because the improvement in macroeconomic management does not appear to have translated into social progress at a satisfactory pace for a large fraction of the South African society. The rate of unemployment remains elevated, averaging about 25 percent in recent years, significantly higher than the rate of 10 percent or less for upper-middle income countries. ${ }^{4}$ Also, South Africa has retained the income inequality of the aparthied era with a Gini coefficient currently over 60, little changed from the level in 1995. The top 20 percent of the population earns over 60 percent of the country's income, and it is estimated that around 50 percent of the population continues to live in poverty. These indicators provide insights into the growing discontent within the South Africa over the benefits of the macroeconomic policies of the Mbeki administration for the social welfare of a large segment of the population. The following section reviews the state of social indicators and assesses whether the social demand gap can be closed with large government expenditures.

\subsection{Social Demands Indicators}

We use the trends in social indicators from the Community Survey 2007 published by Statistics South Africa and Towards a Fifteen Year Review, a comprehensive government progress report which looks at how far South Africa has come in achieving post-aparthied policy objectives. The surveys reveal that South Africa has made progress in the provision of basic services. For example, more than 70 percent of households now live in formal dwellings as of 2007, up 6 percentage points from 1996. The government now regularly removes trash from 60 percent of the households in South Africa, compared to about 50 percent in 1996. From 1996 to 2007, the percentage of households with electricity has increased from less than 60 percent to 80 percent. Households with internal plumbing rose from 32 percent to 47 percent between 2001 to 2007, and those with access to a flushing toilet increased from 49 percent to 55 percent between 2001 and 2007.

\footnotetext{
${ }^{3}$ In fact, the decline in yield rates since 1995 is larger for South Africa than for the declines for United States, so that the spread between the yields of the bonds for the two countries narrowed.

${ }^{4}$ Some sources suggest unemployment higher the 25 percent reported due to the poor quality of the employment data.
} 
There has also been progress in health and education. Between 1996 and 2006, the per capita expenditure on health rose 22 percent. Today, roughly 17 percent of South Africans are enrolled in primary education, much greater than Brazil (11 percent), Romania (6 percent), or Poland (8 percent), but close to Mexico's (15 percent) percentage. Part of these enrollment statistics reflects the demography of Southern Africa, which has a young age structure. Primary education enrollment increased 60 percent since 1980 (36 percent since the end of Apartheid), and the average adult has 6.1 years of education. The number of South Africans with at least some secondary education increased over 30 percent between 2001 and 2007, and the number graduating from secondary school increased by more than 10 percent. Even with this progress, less than half of the population has completed secondary education in 2007, and more than 10 percent had no schooling at all.

However, given how far behind South Africa was, this progress has not been enough to close the social demand gap. For example, the story of South African progress is less favorable when using aggregate measures such as the United Nation's (UN) Human Development Index (HDI), which combines measures of life expectancy, literacy, education, and GDP. South Africa once compared quite favorably to its economic peers: in 1985 South Africa HDI was 0.70, while Turkey had an HDI of 0.65 and Brazil had an HDI of 0.70. South Africa was also far ahead of its regional neighbors: Kenya's HDI was 0.53 in 1985, and Botswana's was 0.62. Ironically, South Africa's HDI score began to decline after Apartheid ended, and today South Africa lags behind its economic peers: South Africa's HDI in 2005 was 0.67 in line that of Botswana and Namibia, and well below the HDI of other middle-income countries; the HDI was 0.83, 0.80, and 0.87 in Mexico, Brazil, and Poland, respectively.

We use education and health expenditures from the UN's Human Development Report to estimate the spending needs on schooling and health care that South Africa would need to reach the middle of its economic peers, which we define as nations of similar GDP per capita in 2006. Our back-of-the-envelope calculations suggest that the expenditures on health care and schooling could raise government's share of GDP anywhere from 125 to 140 percent over a ten year period. ${ }^{5}$ Clearly,

\footnotetext{
${ }^{5}$ Our calculation supposes that South Africa's expenditures on health and education should approach the proportional expenditures of their economic peers. In addition to bringing South Africa's real social expenditures in line with its economic peers, we also took (rough) account of the additional expenditures needed to equalize the level of service. For example, in our schooling expenditure estimates we account for the fact that South Africa would need to spend more to lower its national pupil per student ratio. While other lower middle income nations have average class sizes of 24, South Africa's were higher than 36 in 1995, and still greater than 30 today. We also adjust for age
} 
such a large need cannot be financed through government without compromising macrostability.

\section{Economic Policy, Macroeconomic Stability, and Social Demands}

From the preceding analysis, it appears that South Africa's government would be unable to meet the country's social needs within the budgetary constraints that are consistent with macroeconomic stability. However, there are unique (and likely related) features of the South African economy that suggest that investment in skill formation can allow the country to narrow its social development gap significantly within the next ten years while maintaining macroeconomic stability.

South Africa's economy is very intensive in physical capital. Studies on international comparison of physical capital intensity find that South Africa has one of the highest levels in the world (see M. Samson, Kenneth Quene, and Ingrid van Niekerk (2001) and Raphael Kaplinsky (1995)). At the same time, the country has historically maintained one of the highest unemployment rates, particularly among the uneducated labor force. Findings by Zvi Griliches (1969) and others that physical capital is complementary with skilled labor, but is a substitute for unskilled labor, can rationalize the persistent unemployment rates in South Africa where there is a shortage of skilled labor and an excess supply of unskilled labor. This unique feature of South Africa's economy is a legacy of apartheid era policies which had favored capital intensive sectors and capital intensity of production at the expense of labor-intensive sectors. As a result, South Africa tends to produce and export goods that are skill and capital intensive, a pattern that generally characterizes industrial economies, and does not utilize its abundant labor (Jeffrey Lewis (2002), T. Alleyne and A. Subramanian (2001)). At the same time, the apartheid era policies made quality education inaccessible to the majority of the population, mostly blacks, many of whom were drawn into the struggle against apartheid (see for example Samson, Quene, and van Niekerk (2001)). ${ }^{6}$

structure, which in South Africa requires increased investment due to its relatively larger school-aged population. We also include an adjustment for the fact that South Africa would need to significantly increase expenditures on post-secondary education to reach parity with its economic peers. In our health expenditure estimates we purposefully downplay the role of HIV, so that our estimates are comparable to South Africa's economic peers who do not face such a pressing health crisis. Even with this omission, South Africa's government health expenditures would need to increase dramatically to deliver the quality of service seen by its economic peers (David Evans, Ajay Tandon, Christopher Murray, and Jeremy A Lauer 2001). For example, nearly 60 percent of total health expenditures in South Africa are provided by the private sector (much of this targeted to HIV), while the average for economic peers is less than 40 percent. As such, bringing South Africa's health expenditures in line with economic peers requires large increases in government health expenditures.

${ }^{6}$ Such apartheid-period policies include stringent exchange rate policies that made import of capital goods more affordable, tax distortions (e.g. skewed depreciation rules, investment allowances, payroll levies, and registration fees) that lowered the user cost of capital and made labor relatively more expensive. See also Brahima Coulibaly (2009) 
The mismatch between labor demand (for skilled labor) and excess supply (of unskilled labor) contributes to persistence of the unemployment rate and, therefore, to the lack of significant progress in social development. In the theoretical analysis that follows, we calibrate a simple two-capital growth model to South Africa's economy, and analyze whether a reallocation of resources to human capital formation can allow South Africa to make significant progress toward its social demand objectives while maintaining macroeconomic stability.

\subsection{A Simple Two-Capital Growth Model}

The model of reference is motivated by the Solow growth model augmented with human capital in the spirit of Gregory Mankiw, David Romer, and David Weil (1992). The social planner maximizes

output $y_{t}=A k_{t}^{\alpha} h_{t}^{\beta}$ subject to the following constraints: $y_{t}=c_{t}+i_{t}^{k}+i_{t}^{h}, \dot{k}_{t}=i_{t}^{k}-(n+g+\delta) k_{t}$, and $\dot{h}_{t}=i_{t}^{h}-(n+g+\delta) h_{t}$. Where $\alpha>0, \beta>0$, and $\alpha+\beta<1$. $y_{t}$ is output, $k_{t}$ is the stock of physical capital, $h_{t}$ is the stock of human capital, $A$ is a fixed technology parameter. All variables are in effective units of labor, that is, they are normalized by $L_{t} E_{t}$, where $L_{t}$ is the quantity of raw labor, and $E_{t}=E_{0} e^{g t}$ is labor-augmenting technological progress. Raw labor and labor-augmenting technology grow at constant rates $n$ and $g$, respectively. $\delta$ is the rate of depreciation for physical and human capital, which is assumed to be the same. This is a one-sector production economy in which physical capital, human capital, and consumable goods are perfectly substitutable uses of output. Households own both types of capital as well as labor. Let $s^{k}$ and $s^{h}$ denote the fractions of output invested in physical and human capital, respectively. They are exogenous to the model. Hence, $i_{t}^{k}=s^{k} y_{t}, i_{t}^{h}=s^{h} y_{t}$, and $c_{t}=y_{t}-i_{t}^{k}-i_{t}^{h}=\left(1-s^{k}-s^{h}\right) y_{t}=(1-s) y_{t}$ where $s$ is the national saving rate. Let $\Delta=n+g+\delta$ :

$$
\begin{aligned}
& \dot{k}_{t}=s^{k} y_{t}-\Delta k_{t} \\
& \dot{h}_{t}=s^{h} y_{t}-\Delta h_{t}
\end{aligned}
$$

\subsection{Calibration and Dynamics}

The model is calibrated to South Africa's economy using the following parameters:

for some economic effects the apartheid-era policies. 


$$
g=0.007 \quad n=0.005 \quad \delta=0.060 \quad \alpha=0.3 \quad \beta=0.3 \quad s^{k}=0.2 \quad s^{h}=0.06
$$

The growth rate of labor $(n)$ is consistent with the South African average annual labor growth between 1970 and 2001. $g$ is the average multifactor productivity and $\delta$ is measured as the average annual rate of depreciation for physical capital from 1970 to 2001. The depreciation rate is the ratio of fixed capital consumption to the previous year's capital stock. The data used for the calibration are obtained from the South African Trade and Industrial Policy Strategies database (TIPS). $s^{k}$ is the average fixed capital investment to GDP ratio and $s^{h}$ is the ratio of government expenditures on education, both measures are over 1970-2006 period and are obtained from the Reserve Bank of South Africa. For $\alpha$ and $\beta$, we use an average of various estimates in Mankiw, Romer, and Weil (1992) and Ben Bernanke and Güykaynak Refet (1992). ${ }^{7}$ The initial value of human capital is set to the initial value of capital adjusted by the average rate of investment in physical capital relative to the average rate of investment human capital: $h{ }_{-} 0=k \_0 * s^{h} / s^{k}$. The initial value of physical capital is chosen so that the average output growth in the model matches the average growth of 4.7 percent in the data over the past five years. With these parameters, we can solve the following dynamic system given by equations (1) and (2).

$$
\begin{aligned}
& \dot{k}_{t}^{\text {lin }}=\left[s^{k} f_{k}-\Delta\right] \cdot\left(k_{t}-k^{*}\right)+s^{k} f_{h} \cdot\left(h_{t}-h^{*}\right) \\
& \dot{h}_{t}^{\text {lin }}=s^{h} f_{k} \cdot\left(k_{t}-k^{*}\right)+\left[s^{h} f_{h}-\Delta\right] \cdot\left(h_{t}-h^{*}\right)
\end{aligned}
$$

We use initial conditions to solve for $c 1$ and $c 2$. Figure 2 plots the path of physical capital and human capital, investment in physical and human capital, output, and consumption. An efficient allocation of resources based on the production technology dictates an equal rate of investment in physical and human capital. However, South Africa's investment in human capital has fallen well short of the investment in physical capital resulting in some economic inefficiencies. As a result of the higher physical capital stock, the marginal product of physical capital is lower than that of human capital in the production technology; a one percentage point increase in investment in

\footnotetext{
${ }^{7}$ Bernanke and Gürykaynak (1992) and Mankiw, Romer, and Weil (1992) estimate the share of human and physical capital based on a production function similar to our specification. For the group of non-oil countries and intermediate countries. Bernanke and Gürykaynak (1992) estimated these parameters using both versions 5.6 and 6.0 of the Penn World Tables. The values of $\alpha$ and $\beta$ used in this study is the average of the six estimates for each parameter in these studies.
} 
physical capital to GDP would raise output growth by just to 0.18 percentage points, much lower than the 0.58 percentage points that would be obtained from the same unit of investment in human capital to GDP.

Last year, the government released the Accelerated and Shared Growth Initiative for South Africa (AsgiSA) report for 2007, according to which, the government needs a growth rate of 6 percent between 2010 and 2014 in order to cut the unemployment rate by half to about 12 percent. $^{8}$ This suggests that a sustained 6 percent growth rate over a longer period (ten years) can cut the unemployment rate further to about 6 percent, low enough to allow a larger fraction of the population to provide social services for themselves. Over the past five years, growth of South Africa's economy averaged 4.7 percent, 1.3 percentage point short of the AsigSA objectives. Since a one percentage point investment in human capital raises growth by 0.58 percentage points, the growth objective can be best achieved by raising investment in human capital. A 2.5 percentage point of GDP increase in human capital investment would achieve the 6 percent GDP growth objective. To achieve the same growth through investment in human capital would require a much higher 8 percentage point increase in physical capital investment to GDP.

If the government follows the suggestion to achieve the 6 percent growth objective by raising human capital investment to GDP by 2.5 percentage point, the additional expenditure can be financed out of government budget without compromising fiscal sustainability. The budget deficit for South Africa averaged 0.8 percent of GDP over the past five years. Funding the additional investment in human capital out of the government budget could push the deficit to a larger, but sustainable 3.3 percent of GDP. Also, the additional investment in human capital can be financed by a combination of higher government budget and reduction in defense spending, which averaged over 5 percent of GDP in the last five years, roughly 3 percentage points higher than share of GDP allocated by upper-middle income countries to military spending.

An alternative policy option to obtain the 6 percent growth target could be to reallocate investment from physical capital to human capital. This can be achieved through various policies that raise cost of capital with transfers to subsidize human capital development. Model simulations indicate, that the 6 percent GDP growth objective can be achieved with a reallocation of 5

\footnotetext{
${ }^{8}$ The AsgiSA was launched by Deputy President Phumzile Mlambo-Ngcuka in February 2006. After research and discussion with stakeholders, government identified the "binding constraints on growth" that needed to be addressed so as to progress in order to achieve its target of halving unemployment and poverty between 2004 and 2014. This could be achieved if the economy grew at an average rate of at least 4.5 percent in the period to 2009, and by an average of 6 percent in the period 2010 to 2014 .
} 
percentage point of GDP from investment in physical capital to investment in human capital, and would require no increases in the government's budget.

To be clear, the share of South Africa's GDP devoted to education is in line with the 5 percent for other upper-middle income countries, and the 18 percent of government expenditures allocated to education exceeds that of its peers by 4 percentage points. But, because of the legacy of apartheid that held back skill formation, South Africa needs to further increase investment in human capital in order to make up for past under investment. However, skill formation alone would not guarantee a significant reduction in unemployment unless it is also accompanied by reforms in the labor market. World Bank index on labor market rigidity put South Africa at 44, much higher than the average of 33 for upper-middle income countries. ${ }^{9}$ Flexibility of labor markets would be necessary for the absorption of the newly formed human capital.

\section{Conclusion}

The balance between macrostability and social demands has been a constant policy dilemma for post-apartheid policy markers. The macro stability objectives have generally been achieved, but progress on social demand has been slow and below the expectations of South Africans. Social demand indicators for South Africa are generally below those of its economic peers. The slow progress to eradicate the social needs has tilted the balance of power in public policy in favor of Jacob Zuma, portrayed as a populist who will increase spending on public works and social demands, and undermine macrostability. As Zuma assumes power, the main question looming over his mandate would be whether and how he will shift the balance of these two policy objectives. The analysis in this paper suggests that both objectives are attainable over the course of the next ten years if policy is geared toward increasing skill formation. Higher human capital will allow the labor market to absorb a significant portion of the excess supply of labor. With lower unemployment, a large fraction of the population will be able to afford its social needs. However, labor markets would need to be more flexible, and continued attention should be given to the scourge of AIDS/HIV, which could decimate labor and have offsetting effects on the formation of human capital stock.

\footnotetext{
${ }^{9} 0=$ least rigid, $100=$ most rigid
} 
Figure 1: Macroeconomic Indicators of South Africa's Economy

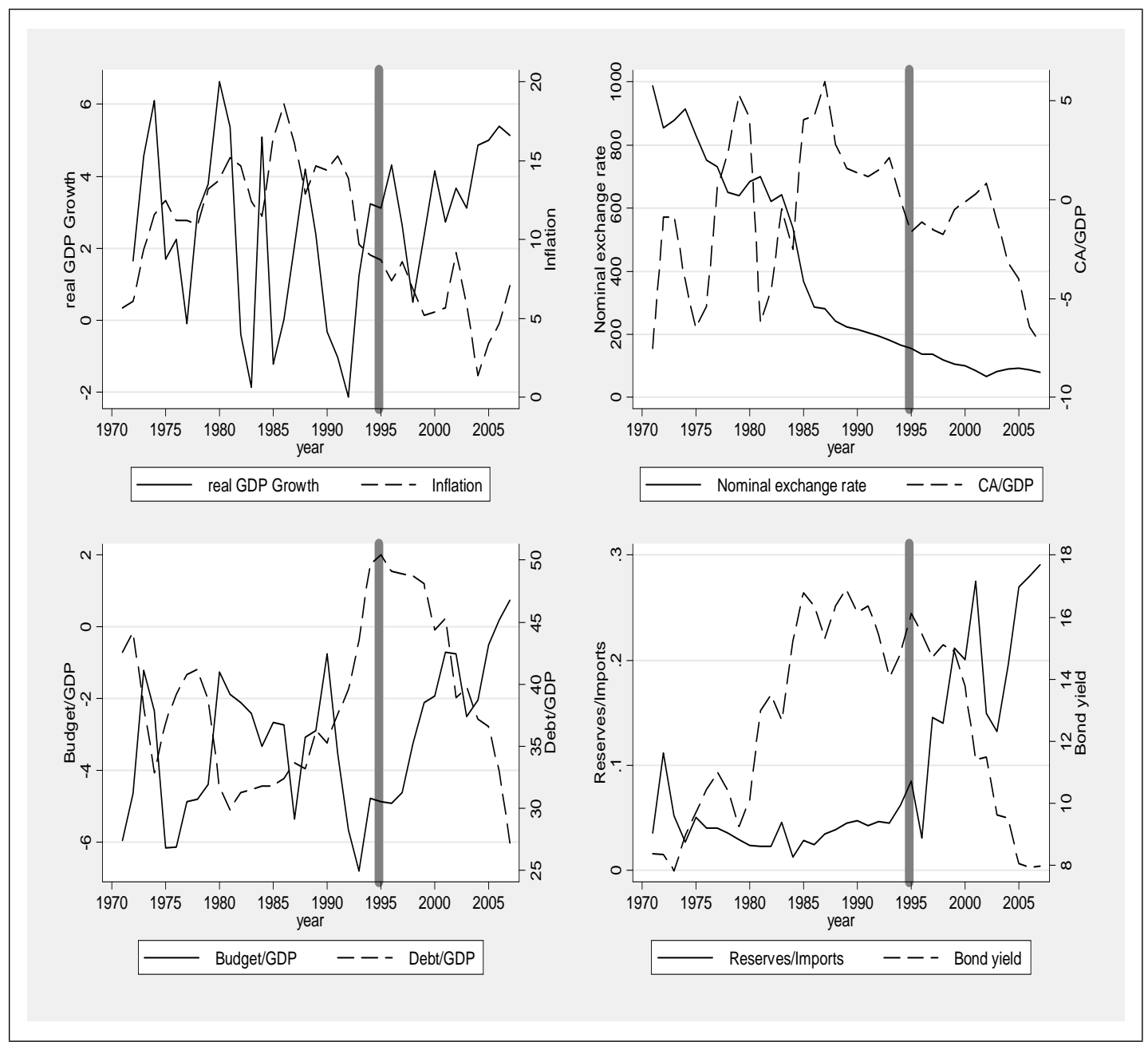

GDP is the gross domestic product. Inflation is the consumer price inflation. Exchange rate is the trade-weighted nominal exchange rate. CA/GDP is the current account balance to GDP ratio. Budget/GDP is the fiscal balance to GDP ratio. Debt/GDP is the government debt to GDP ratio. Reserves/Imports is the ratio of foreign exchange reserves to imports. Bond Yield is the yield on bonds with maturity of 15 or more years. Data are obtained from the South Africa Reserve Bank. 
Figure 2: Effect of various policy scenarios on South Africa's Economy

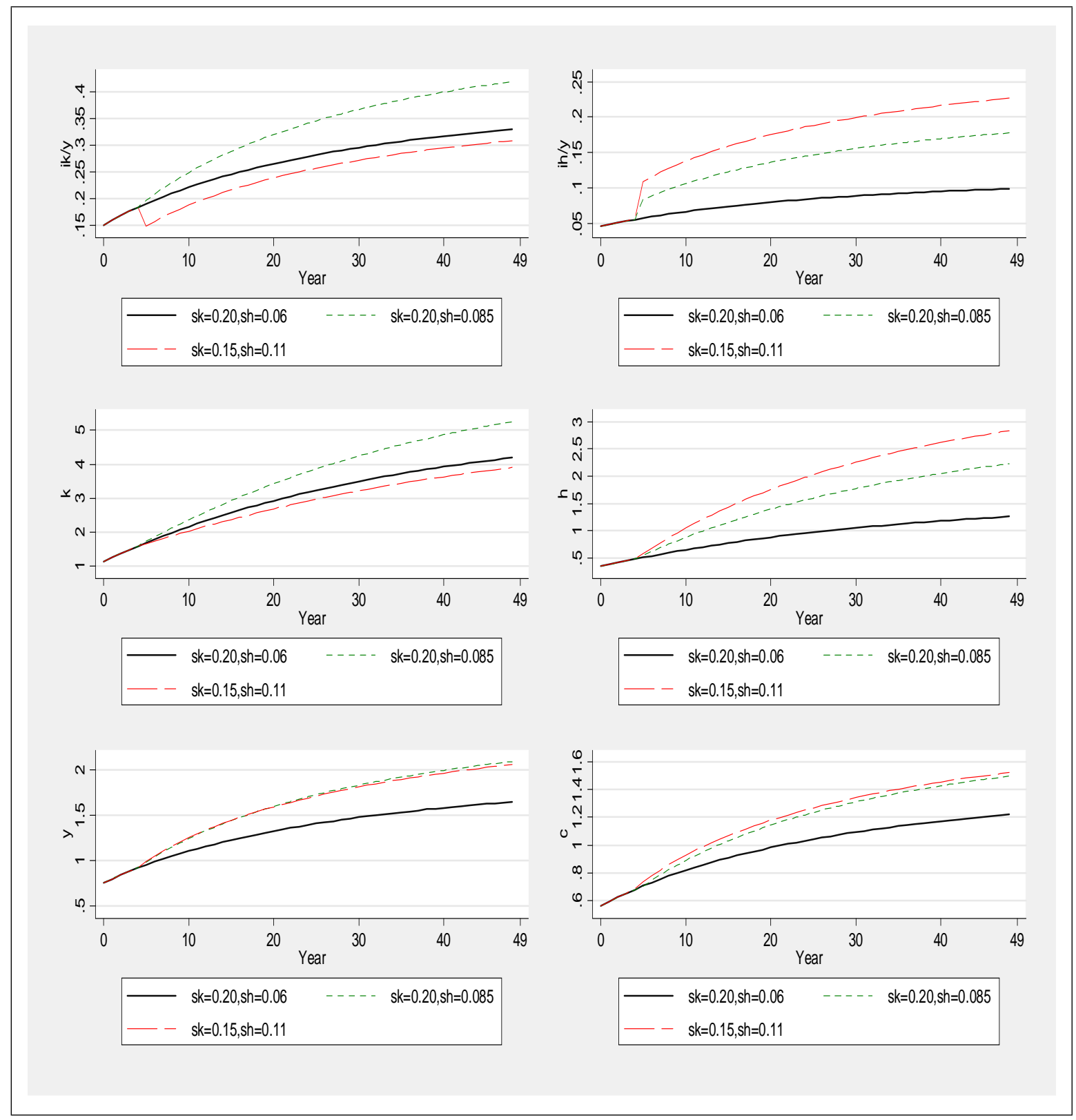

$\mathrm{ik} / \mathrm{y}$ and ih/y are investment in physical and human capital to GDP ratios, respectively; $\mathrm{k}$ and $\mathrm{h}$ are physical and human capital stocks; y and c are output and consumption, respectively.

Source: Data are from from authors' simulation of a two-capital growth model calibrated to South Africa's Economy. 


\section{References}

[1] Alleyne, T., \& Subramanian, A. (2001). What does south Africa's pattern of trade say about its labor market? IMF working paper, WP/01/148. Washington: International Monetary Fund.

[2] Coulibaly, Brahima (2009). "Effects of Financial Autarky and Integration: The Case of the South Africa Embargo", Journal of International Money and Finance 28, pp. 454-478.

[3] Bernanke, Ben S. and Gürkaynak S. Refet (2001). "Is Growth Exogenous? Taking Mankiw, Romer, and Weil Seriously", NBER Working Paper No. 8365 (Cambridge, Massachusetts: National Bureau of Economic Research)

[4] Evans, David, Ajay Tandon, Christopher Murray, and Jeremy A Lauer (2001). "Comparative Efficiency of National Health Systems: Cross National Econometric Analysis." British Medical Journal 323(7308):307-10.

[5] Griliches, Zvi (1969). "Capital-Skill Complementarity," Review of Economics and Statistics 51(4): 465-468.

[6] Kaplinsky, Raphael (1995). "Capital Intensity in South Africa's Manufacturing and Unemployment, 1972-1990" World Development, Vol. 23, No. 2, pp. 179-192.

[7] Lewis, D. Jeffrey (2002). "Promoting Growth and Employment in South Africa" Africa Region Working Paper Series, Number 32.

[8] Mankiw, N. Gregory, David Romer, and David N. Weil (1992). "A Contribution to the Empirics of Economic Growth," Quarterly Journal of Economics 107 (2): 407-437.

[9] Samson, M., Kenneth Mac Quene, and Ingrid van Niekerk (2001). "Capital/Skills-Intensity and Job Creation: An Analysis of Policy Options," Trade and Industrial Policy Strategies Forum, September 2001.

[10] South Africa Government Communications (2008). Towards a Fifteen Year Review. Government Publication. Pretoria, South Africa.

[11] Statistics South Africa (2007). Community Survey 200\%. Government Publication. Pretoria, South Africa. 